\title{
Sickle Cell Anemia and Family Taboo: The Experience of a Sister of a Sick Child in Cameroon
}

\author{
Hassan Njifon Nsangou ${ }^{1,2, *}$, Regine Scelles ${ }^{2}$ \\ ${ }^{1}$ Department of Philosophy-Psychology-Sociology, University of Dschang, Dschang, Cameroon \\ ${ }^{2}$ Clipsyd Research Group, University of Paris Nanterre, Nanterre, France
}

Email address:

hassannji75@yahoo.fr (H. N. Nsangou)

${ }^{*}$ Corresponding author

\section{To cite this article:}

Hassan Njifon Nsangou, Regine Scelles. Sickle Cell Anemia and Family Taboo: The Experience of a Sister of a Sick Child in Cameroon. American Journal of Pediatrics. Vol. 6, No. 3, 2020, pp. 190-198. doi: 10.11648/j.ajp.20200603.14

Received: April 10, 2020; Accepted: April 26, 2020; Published: May 15, 2020

\begin{abstract}
Sickle cell anemia is the most prevalent genetic disease in the world that is seen as a taboo in African communities where single-child families are rare. However, speaking with a family about a pathology or a disability reduces the harmful effects in the sick child as well as on the members of his family. This research aims to understand the psychological impact of family taboo on sickle cell anemia on a sister of a sick child in Cameroon. This knowledge will enable professionals to further improve support for sick children by taking into account their family and siblings and making them a resource for both the sick child and their siblings. We met a 17-year-old girl without sickle cell anemia who is the second child of a family composed of seven children including five girls and two boys. She is the older sister of the only sick child in the 13-year-old siblings. The meeting took place in Cameroon at the home of her parents who allowed her to participate in the research by signing a consent form. We collected data through an interview about the illness, her relationship with her sick sister and with her family members. Following the interview, we invited her to make a drawing of her family. We analyzed the interview according to the thematic approach. The interview and drawing of the family were two complementary tools to better understand the experience of this girl. The family taboo about the illness causes the girl to feel strange about her sick sister and her illness. It makes her powerless in the face of crises of her sister. This helplessness arouses her feelings of guilt and to have aggressive behavior against her sick sister she thought to be a passive victim of the disease and a child to be protected. The mother's order concerning the protection of the sick child by her siblings gives the girl a feeling of abandonment and non-recognition of her experience as a sister of the sick child by her parents in general and by her mother in particular. This article shows the need to remain extremely sensitive to how the experience of the disease fits into the family dynamics in order to transform it and to make family and siblings a resource for the sick child and for his siblings.
\end{abstract}

Keywords: Sickle Cell Anemia, Culture, Taboo, Siblings, Cameroon

\section{Introduction}

Sickle cell anemia is a genetic disease that confronts the affected child and his family with its painful and chronic crises associated with its physical changes, its regular and expensive hospitalizations, and its death thought to be imminent. It remains a taboo disease in Cameroonian families where it is difficult to meet families with less than five children [2]. Few studies have examined the psychological impact of this taboo on siblings of children with sickle cell anemia. The possibility of telling a traumatic event is important in mitigating the impact of effects it generates on the subject.

This article presents the psychological repercussions of the family taboo concerning sickle cell anemia on Fidèle, a sister of an affected child in Cameroon. It includes the analysis of an interview, a drawing of the family made by a child in the context of a research whose framework, and method will be briefly recalled. It highlights the complexity of the experience of this young girl and her parents faced with sickle cell anemia and the taboo concerning this disease. Its objective is therefore to build on this knowledge to open up the design of care devices that better take into account the family and brothers and sisters of children with sickle cell 
anemia.

\section{Theoretical Considerations}

\subsection{Sickle Cell Anemia: A Serious and Fatal Genetic Disease}

Sickle cell disease is the most prevalent genetic disease in the world with approximately 500 million people carrying the sickle cell trait and 50 million people with the disease worldwide [3]. Initially distributed in malaria-endemic areas like sub-Saharan Africa, migratory movements of populations have gradually changed its distribution around the world [4]. Consequently, this disease is present in practically all the countries having the populations originating in Africa and the regions around the Mediterranean [5].

Africa is the continent most affected by sickle cell disease with a prevalence rate of $2 \%$ in the general population and an estimated mortality of more than $70 \%$ in children under 5 years of age [6]. Cameroon is one of the countries most affected by this disease with a prevalence of $8.34 \%$ in the general population [7]. In Africa, sickle cell disease management is costly and the unavailability of bone marrow transplantation and gene therapy, the only effective treatment for seizures, means that deaths of children under the age of 5 are numerous [8].

Discovered in the United States of America in 1910, sickle cell anemia is an autosomal recessive pathology transmitted to the child by both parents. It is due to the presence, in the blood, of an abnormal hemoglobin, which leads to a deficit in the oxygen supply of the different organs of the body by red blood cells that have a reduced lifespan. The rapid destruction of red blood cells leads to unpredictable anemia and chronic pain [9] with which the patient identifies [10], resulting in multiple hospitalizations and expensive care for parents of affected children [11].

\subsection{Sickle Cell Anemia: A Figure of the Persecution}

In sub-Saharan African cultural context, the disease is thought of as an "evil" capable of attacking all family members, including after the death of the patient $[12,13]$. The sick child is immersed in a society structured by prohibitions, rites and traditional attitudes of which women are the custodians [14]. A child's illness or disability is part of this cultural structure, which gives it meaning and produces effects.

Sickle cell anemia is thought to be a manifestation of the possession of the sick child and his family by a sorcerer or by an evil spirit $[13,15,16]$. It can also be experienced, depending on the case, as a request from the ancestors to repair a transgression of an ancestral norm, addressed to the family of the patient [17]. Generally, the mother is designated as responsible for this transgression; the overprotection of the affected child, by her and by the members of the family, constitutes a defense allowing them to exculpate themselves and to register the child in the history of the family [17].

\subsection{Sickle Cell Anemia: A Family Taboo}

Talking about sickle cell anemia is taboo among African and African families. As a result, children with this disease more often find it difficult to talk about their illness and to verbalize their experience [5].

Parents hide the name of the disease from children or some of them and that children hide their knowledge of the disease from their parents [18]. According to the study [18], this taboo constitutes, for children, a means of protection for their parents and for the latter the desire not to aggravate the suffering of children. The author also points out that parents make this taboo a means of protecting sick children from social and family stigma.

Parents are indeed pessimistic about the future of the affected child and want to continue to invest in this future with hope. They may then think that not talking about the disease would protect their child from this fatal becoming or would not cause the disease to exist in a movement of magico-religious beliefs [19].

\subsection{The Speech Containment and Transformation Function}

Speech has a potentially soothing effect and has a communicative, affective and containing function for the subject and those close to him. The speech released between parents and children releases that which can unfold between children, which favors the movements of identification and differentiation between them, the founders of their sibling relationships [20]. This "good experience" with an adult allows the child to experience the benefit of "thinking together" in a co-construction of a narrative on the pathology [20]. It is in this "thinking together" that the pathology is best able to fit into time, time of the sick subject, time of the other, time of his home groups.

The narrative of the disease has a defensive function like secondary development for the dream, and the possibility of telling a traumatic event is crucial in mitigating the impact of suffering for the sick child and for loved ones [21]. The defensive function of narrativity also opens up possibilities for creativity, the work of thought it implies being both restorative and inventive. Therefore, talking to the child, with the child and his brothers and sisters about his illness can help each of them to contain it, think about it and transform it.

Speaking between children and adults about the disease is beneficial for everyone and has a capacity to contain and transform the trauma that constitutes the disease [22]. The negative pact [23] can have a transient protective effect for the sick child, his parents and his brothers and sisters if it does not last too long.

\subsection{General Information on the Experience of Brothers and Sisters of Sick Children}

The illness of a child has repercussions on his brothers and sisters who experience ambivalent feelings concerning him such as shame and guilt, love and hate, complicity and rivalry, anxiety and the desire for death concerning the sick child [22]. In order not to worsen the suffering of their parents and that of 
the patient, his brothers and sisters often keep their suffering silent [24].

Regarding sickle cell anemia, psychological studies focus on the mental suffering of affected children and that of their parents $[8,9,17,25]$. The experience of their brothers and sisters is most often studied from the parents' accounts. Overprotection of the child with sickle cell disease leads parents to gradually divest care of other children [26]. The latter experience an emotional breakdown resulting in a feeling of rejection, marginalization and exclusion on the part of parents and the extended family [13, 15, 16, 27]. They show jealousy towards the patient whom they designate as the main person responsible for crises, which destabilize the family financially, and emotionally $[15,28]$. They feel guilty for having negative thoughts such as jealousy towards him; they see themselves as "bad brothers" [15, 29]. Their experiences are generally influenced by parental intrusions in their relationship with the sick child. Elders or juniors of the affected child, they are often parentalised by the parents. In the absence of the parents, they are the ones who supervise the sick child. This ranges from daily monitoring, taking treatment and observing medical instructions by the patient [18], to the patient's bodily care and assistance during hospitalizations [19]. The great implication of the sisters of sick children in the follow-up of the sick is explained by the education of girls who, in sub-Saharan African societies, has main objective to make them mothers, therefore people likely to take care of children [16].

\section{Method}

\subsection{Meeting Conditions and Ethical Arrangements}

This article is the result of research done with families with a child suffering from sickle cell disease in Cameroon, located in the heart of sub-Saharan Africa where the floor is given; a subject who talks about himself, others or anything else, is supposed to have been authorized by his group, by his family to do so [30]. In this country, parents speak to professionals about their children who have the obligation to listen and speak only when adults allow them to do it [31]. Talking about sickle cell disease with them is not straightforward and requires the researcher to form an alliance with the family.
This research, which took place in Cameroon, worked to get parents to allow their children to speak to the researcher. In fact, the child must not speak to a stranger, to an adult about intimate family matters, at the risk of becoming a "child of shame" as defined by [32].

The parents designated which of their children would participate in the research. These children were not only allowed to speak, but were tasked with speaking to the researcher. The system includes an individual interview with each child and a drawing, preceded and followed by a "group" time. Before the interview, the mother, in front of the whole family, talks about the relationships between her children and those who will participate, the children listen and are silent. After the drawing, the adults ask the researcher and the child about the content of their meeting. It is therefore an individual meeting but which takes place in a group device allowing the children to speak as freely as possible.

Fidèle is the child who is the subject of this research. Fidèle's mother was met at a meeting of the Association of Parents of Sickle Cell Children of the Chantal Biya Foundation in Yaoundé, to whom the object and methodology of the research were presented, as well as its inclusion criteria. Some participants. Fidèle's mother, like eight other parents, registered as a volunteer to participate with her family in this research. The meeting with his family and with Fidèle took place at his parents' home 3 days after the association's meeting. For ethical and confidentiality reasons, the data have been anonymized and fictitious first names attributed to the participants.

The mother, in the father's absence, signed the consent form regarding Fidèle's participation in the research. Fidèle was reminded of her freedom to participate or not to participate in research. Fictitious first names were given to participants to ensure the anonymity and confidentiality of the research. The tape was destroyed after the interview data was transcribed.

\subsection{Fidèle and Her Siblings}

Fidèle's siblings grew up in a polygamous family. The father, aged about sixty, a retired public servant became an entrepreneur in the field of public works, after several years spent with his first wife without having children, he married Angela's mother, housewife with whom he had 7 children, 5 girls and 2 boys.

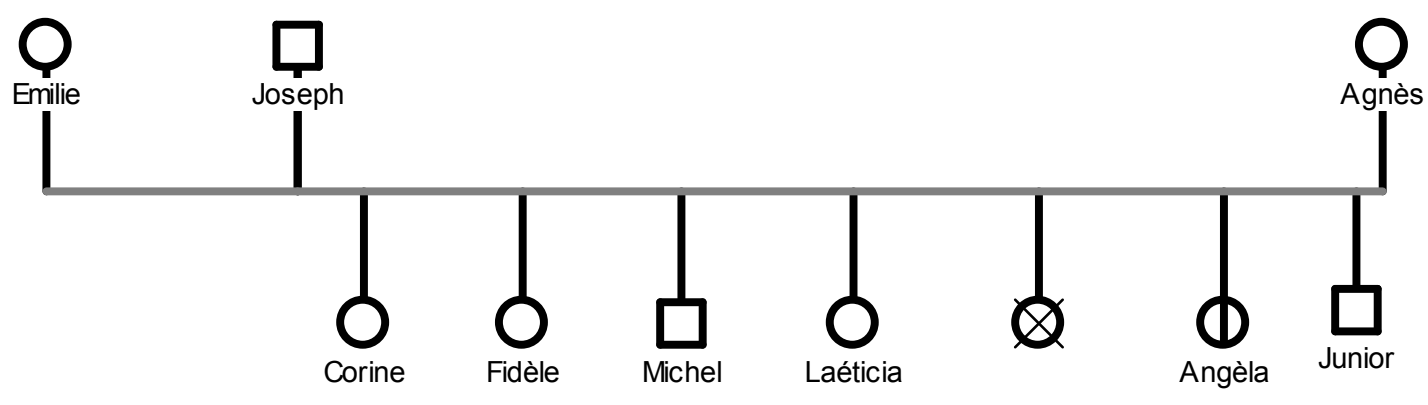

Figure 1. Familial genogram of Fidèle.

17 years old and a pupil in first class, Fidèle is the second child of her siblings. Her mother is very calm and very maternal towards her younger siblings in general and Angela describes her in particular. Angela is a young girl with sickle cell anemia, 13 years old, pupil in class of Middle Course, first year and penultimate born of siblings A girl who died before 
the age of 2 years; the cause of death is not known, but everything suggests, according to the mother, that she died as a result of sickle cell crises. Angela is the only child with sickle cell disease in the siblings. His illness was diagnosed at the age of 7 during one of his regular hospital admissions for generalized attacks of pain all over his body; main manifestation of his illness. These crises lead him, once or twice a month, to spend a short stay of about 2 to 3 days in hospital.

\subsection{Data Collection and Analysis}

The data was collected through an interview followed by a drawing of the family. The interview with Fidèle, recorded via a dictaphone, touched on her relationships with her brothers and sisters, with Angela and with her parents. She was also touched on what she thinks about sickle cell anemia and her sister's seizures, while also getting her to say, to express herself as Angela's sister. At the end of the interview, Fidèle was invited to draw a picture of his family on a sheet of paper with colored pencils available to him. The drawing was done based on the protocol of the study [1] with the instruction "I would like you to draw your family on this sheet".

The interviews were the subject of a thematic analysis and the drawing, of an analysis according to the grid of the study [1] with a consideration of cultural specificities [16, 33].

\section{Results}

The results highlight, through the interview and the drawing of the family, the psychological impact of the family taboo concerning sickle cell anemia on Fidèle.

\subsection{Talking or Not With Family}

Fidèle maintains, in family, a specific relationship with the sharing, with the members of the restricted and / or extended family, of his experience concerning his sick sister and his illness.

Keep your life quiet to protect your parents and siblings.

Fidèle says of his parents' experience with his sister's illness that "They are often worried. They are also afraid. I do not want to aggravate their discomfort. If I say to the parents, it's a bit like I'm reinforcing their concerns. "Here, there is mutual protection between parent and child via the family taboo on the disease and on the experience of the disease. Fidèle knows that her two parents are suffering. She wants to help them and alleviate their suffering. For this, she is ready to "lose" her place as a sister [22]. She therefore maintains this taboo so as not to psychologically contaminate her mother with her suffering. The taboo reflects Fidèle's recognition of her mother's suffering and her desire not to worsen this suffering.

\subsection{Sickle Cell Anemia, a Disease Spoken out Through Patient Care and Protection Orders}

The disease is spoken of as a family through parental and fraternal orders concerning the care and protection of the patient. Siblings and other family members don't talk to each other about how they feel and experience Angela's illness. The parents in fact care for the brothers and sisters of the sick child. Their involvement by the parents in protecting and monitoring Angela does not allow them to say and tell themselves what they are going through with her. Expressing or talking about their experiences to parents, adults and brothers and sisters seems to them to be illegitimate, not authorized.

The only discussions between adults and children concerning Angela's disease relate primarily to the behavior to be taken by brothers and sisters to avoid or limit her crises. Fidèle and his brothers and sisters are in fact receptacles of these parental injunctions, which pay little interest to what they live concerning the illness of their brother. This creates in her a sense of abandonment by the family in favor of her sick sister who draws the family's attention to her. This feeling of abandonment is accompanied by a feeling of jealousy towards Angela who, too, is kept away from any word concerning her illness with her brothers and sisters.

\subsection{The Feeling of Strangeness About the Sick Sister}

Fidèle expresses his anger against Angela who cannot tell her how she feels during her attacks. "When she is sick, she cries, she only cries. It pisses people off. " The absence of words to express her experience of the illness and, ultimately, to describe herself as a sick sister, makes Angela to Fidèle. The absence of this word leads Fidèle not to be able to represent his sick sister. There is, in fact, in this family, the absence of a ready-to-think group or family that can structure and contain the experience of children concerning Angela's disease, which remains strange.

Fidèle's suffering lies in her difficulty in telling her parents, brothers and sisters and her sick sister what she feels and experiences regarding her illness. This suffering reflects his desire to have power over his sister's illness, to make sense of it through a precise representation of his crises. She also translates at home the alteration of the identification / differentiation mechanism with the sick sister. Angela remains a strange person who arouses a suffering and a feeling of helplessness in Fidèle; helplessness in the face of crises which cannot be avoided or eliminated, and helplessness in the face of a sister from whom it is difficult to imagine.

Not understanding what the sick sister is going through concerning her illness and what is going on in her body and not representing her crises, leads Fidèle to ask questions about herself and her own identity when we know that children's ego is built through the process of identification and differentiation from others $[22,34,35]$.

\subsection{The Feeling of Guilt}

Angela's seizures give Fidèle the image that she is a bad sister. She says, "When she gets sick somewhere I start to think it may be because I have been pulling her ears lately. I am not free to educate him. She can do stupid things, I see her, with a great desire to correct it. With her illness, I can do nothing. However, when the nonsense accumulates, sometimes I find 
myself typing it unintentionally. It is after typing it that I start to regret. "Fidèle therefore wants to educate her sister. This desire comes up against the vulnerability of the sick sister. The education Fidèle talks about is actually protecting her sister from crises.

We can see how, having to know what her sister is going through, failing to speak with her about her experience, Fidèle becomes aggressive against her. This aggressiveness has here a function of creating a link between her and her sick sister. It not only translates the psychological elaboration of finding meaning concerning the crises of this sister who does not speak about it but also her desire to enter into contact with this sister who is distant and who constitutes for her a broken mirror [36] which sends her a strange image of herself.

Fidèle is convinced that her sick sister is considered a bad sister. She says, "It hurts me too much. I know when she is in pain; she needs us to help her. However, we do everything, her illness does not end. It is all that hurts when I see her suffering like that". It is as if between brothers and sisters, it was not a question of games and exchanges with the patient, but of a relationship aimed at the never-completed repair of the latter's vulnerability. This marks the difficulty of Fidèle and her brothers and sisters in living as "brother of" Angela.

\subsection{Contribution of the Family Drawing}

Between the interview and the drawing, a 5-minute break was planned to allow the child and the researcher to recharge their batteries and rest. This non-mandatory break was designed to make the meeting less exhausting for the child and for the researcher. Fidèle wanted to take a break during which she stayed in the living room, without going out. The interview would have been exhausting for Fidèle. It is also possible that she took this break to better prepare the drawing or to better think of the family and the people to draw.

\subsubsection{The Incomprehension of the Instruction}

Fidèle, after hearing the drawing instruction "I would like you to draw your family to me", said that she did not know how to draw. Following a reformulation of the instruction, she approached the table and stopped, as if to mentally structure an image of her family, of the family to be drawn.

Between the reformulation of the instructions and the start of the drawing, Fidèle's gaze wandered over the different photos of families hanging on the walls of the living room. The girl then drank a glass of water before starting to draw. This shows that her drawing mobilizes complex affects in her and shows an inhibition that already appeared in the interview.

\subsubsection{Parents' Investment}

The drawing was done very quickly. The family was simultaneously drawn, by order, without correction or improvement, the different members of the nuclear family; father (Joseph), mother (Agnes), first sibling (Corine), participant (Fidèle), younger brother (Michel), younger heart (Laéticia), younger sister with sickle cell disease (Angela) and the youngest sibling (Junior). The table, placed in the center of the sheet, on which a bouquet of flowers is placed, is the last element drawn. This order of appearance in the drawing provides information on the emotional investment of relationships with parents. With this drawing, Fidèle highlights her parents, the importance she gives to her subjective relationships with her father and mother.

The stepmother (Emilie) is absent from the drawing. She drew a monogamous family. This absence may reflect the possible family conflicts witnessed by Fidèle within this polygamous family. In this way, she can translate an alliance with her mother in possible conflicts between the latter and her co-wife. In fact, sickle cell anemia often rekindles conflicts between co-wives who blame each other for the onset of the disease [17].

After finishing his drawing, Fidèle handed it to the researcher, with a smile. She asked not to make fun of it. We collected the sheet and placed it on the table. Then, as required by the protocol, he was asked to comment on his drawing. This request not to make fun of his drawing is in fact a request for recognition of his experience; a recognition that his family does not show towards him, as the interview shows. Therefore, it is a request to her family regarding her experience as Angela's sister. She also informs about the difficulty she has in "giving herself", in "revealing herself" to the members of her family, in telling them what she experiences and what she thinks daily regarding her sick sister, her illness and her family.

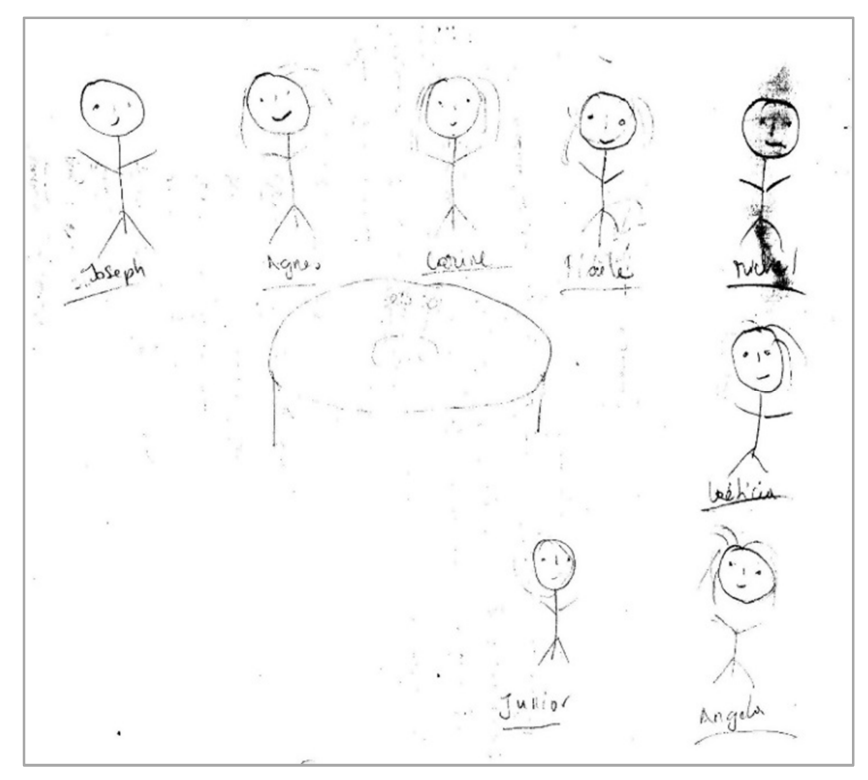

Figure 2. Fidèle's drawing.

\subsubsection{The Expression of Anger at the Sick Sister}

Faithful says he drew his family members in the living room talking about the school year. From his drawing, Fidèle designates his father (Joseph) as the happiest character. He is actually happy because, she says, all of the children have worked well at school. She designates Fidèle's younger brother (Michel) as the least happy person in the drawing, "because she does not express his emotions". In a social context where it is forbidden to enter into conflict with his parents [16], this complaint can be understood as a 
displacement on this sister of the complaint against the parents who do not express not their experience of the disease with children and who do not allow them to express their own. Faithful translates by this anger his desire to see

1. His parents tell children about sickle cell anemia

2. His brothers and sisters talk about sickle cell disease among themselves

3. His sick sister talks to him and talk with his other brothers and sisters about his experience of the disease

The mother is considered the nicest person because she takes good care of everyone. The sick child is considered the least kind person in the drawing because " We often get sleepless nights here at home and even in the hospital". Fidèle thus expresses her anger against her sick sister whom she designates as responsible for the suffering of the family. Faithful therefore thinks of himself as a victim of his sister's illness.

\subsubsection{Identification with the Father}

If Fidèle had been asked to take the place of a person in the drawing, she would have taken that of her father (Joseph) because he is the family's decision-making center. She manifests her identification with the father and translates his desire to have power, like his father, within the family.

By identifying with his father, it is possible that Fidèle wishes to have the power necessary to reconfigure family relationships and lead parents, the mother, to no longer emotionally isolate non sick children and by allowing family members to speak about sickle cell anemia and their experience in connection with this disease and the sick child.

\subsubsection{Parents Named}

Parents and other people in the drawing are designated by their first names. This "first name" of the parents can reflect, among other things, the lack of internalization of the social norm. Indeed, it is not usual to see a child, in Cameroon, calling his father by his first name. The father is usually called "dad" and the mother is "mom".

This behavior can also reflect an oedipal conflict with the parents, a desire and a quest for autonomy for this young girl vis-à-vis her parents. Faithful is actually a young teenager. Therefore, behavior can be associated with the adolescent process.

\subsubsection{The Presence of Angela and Fidèle on the Drawing}

The sick child is present in the drawing despite the fact that she is thought to be strange in the interview. This strange child should, in principle and in accordance with the pleasure principle, be excluded from Fidèle's mental universe because it constitutes for her a kind of broken mirror which sends back a bad image of herself [36]. The presence of Angela in this drawing can reflect the Faithful desire to understand what is happening to this strange sister and the intensity of the psychological elaboration related to this sister and to her illness. She is actually a sister who, despite her strangeness, is present in Fidèle on the psychological level.

The drawing highlights the effort she makes to make this sister less strange, efforts that run up against the taboo of the disease, the parents' refusal to allow family talk about this disease. Fidèle's presence on the drawing reflects his feeling of belonging to his family. All the characters are similar, with a more noticeable gender difference in the head. Females have hair unlike males. All these people are drawn in sticks and do not touch. They are roughly similar people, apart from the difference in sex perceptible by the absence or presence of hair as mentioned above. This similarity of cartoon people may reflect Fidèle's recognition of the suffering of other family members who, like her, cannot tell others what they are going through about Angela's illness. She can also refer to Fidèle's alteration of the identification/differentiation mechanism with her brothers and sisters. It is possible that Fidèle translates this as his difficulty in thinking of his brothers and sisters as likely to experience Angela's illness decently.

No one in the drawing is in physical contact with others. This can mean the feeling of emotional isolation that Fidèle experiences within his family and his recognition of that experienced by other members of his family. However, we are in a cultural context where the expression of affection and support does not always translate into physical contact [37] such as touching, kissing and caressing, among others.

\section{Discussion}

One of the results that sparked discussion was the identification of Fidèle with his father. The father is the guarantor of the family taboo concerning sickle cell anemia. This identification highlights the psychological transmission of the taboo to this girl by her parents. Transmission can be represented by projective identification with the parent; the subject inherits narcissistic needs, has a mission of narcissistic continuity, and repair vis-à-vis the parents [38]. This research shows how Fidèle, forced by her parents to fit into the taboo of sickle cell anemia, strives to break this transmission by asking for recognition of her experience as well as that of her brothers and sisters by her parents in connection with the disease.

Parents in general and the mother in particular are very present in Angela's relationships with Fidèle and with her other brothers and sisters. This parental surprise, characterized by injunctions made to the brothers and sisters of the sick child by his parents concerning his monitoring and protection hinders the process of development between children, of their lived experience in connection with the disease. The sick child is indeed considered as a passive victim of the disease and not as a brother. He is a fragile and vulnerable child whose duty and obligation to protect without trying to find out what he feels or experiences with his illness. Therefore, siblings are a resource neither for the sick child, nor for his brothers and sisters. It is known that if the adult is important in helping the child to find the words, the images to elaborate about disease, brothers and sisters prove to be also a precious resource, if their parents, taking into account the defensive function of family pacts [39], implicitly or explicitly authorize them. Furthermore, overprotection of the sick child can lead, if it persists over time, to emotional dependence and lack of autonomy in his future social relationships; as noted [16]. 
As a family, the disease is not spoken of. No one explains and / or tells the children why it should not be talked about. Would it bring bad luck and would there be a family weakness that should be hidden? Do children say nothing by what they do not know or because they do not have the words to say, what they experience and what they perceive and feel in connection with the disease? Can only adults talk about it among themselves, with doctors, traditional healers only? Above all, where does this ban come from, what is its function? This ban would come from the educational style of children within sub-Saharan African families and from the representation that families have of sickle cell anemia as presented in the literature above. Therefore, how to know what must/can say, how to say when the mother, carrier and protector of this unspoken, asks the child to speak without telling him what he can / must say and how to say what is forbidden to say?

It is possible that the researcher has acquired, with Fidèle, the status of "mediator", through / through whom they hope to make themselves understood by their relatives and care institutions. Having taken the time necessary to meet her and to listen to her without judging her led Fidèle to attribute this status to the researcher. This status is generally attributed to researchers who, in the field of education sciences for example, meet families in their homes confronted with schooling problems [40]. Families as people through whom they can make their difficulties heard by educational institutions therefore often invest them.

Thus, Fidèle may have felt in difficulty in the face of a demand that was not necessarily clear. In this context, the details and reassurance of the researcher are important and essential, but cannot completely hide these difficulties due to the protocol itself and the theme addressed. The paradox can be situated and understood, from Fidèle's point of view, at several levels of injunctions coming from the parents and more particularly from the mother:

In family we do not talk about the disease

1. You can / should tell the researcher about the disease here at home

2. I am not telling you what you can / must say and how you can / must say, you must know.

Faithful, in this case, faced a "double constraint" or a "paradoxical injunction" [41]. She was allowed by her parents to speak with the researcher about a subject they are not often allowed to discuss with family, at home. This leads to asking questions about the role, place and / or status of the researcher in this system, from the Faithful point of view. The latter could have had, through the researcher, the possibility of making her lived experience heard by her parents, her mother, her sick sister, her other brothers and sisters and the care institutions.

\section{Conclusion}

This article presents results similar to those of other works concerning the presence of the sickle cell anemia taboo in African families [4, 11]. Absence of speech reinforces the feeling of abandonment of the girl and her feeling of strangeness about her sick sister and her illness. This can pose a risk to his psychological health if it persists over time. Following other work [20, 21, 24, 42], this article shows the need for the professional to remain extremely sensitive to the way in which the experience of the disease is registered in the family psychology. This can help to make the family and siblings a resource for the child with sickle cell disease and his brothers and sisters. The establishment of a space for discussion between the sick child, his brothers and sisters, his parents and the care professionals within the institutions can help to achieve this objective and reduce the potentially harmful effect of the family taboo concerning sickle cell disease on the sick child, on his brothers and sisters and even on his parents. The negative pact [23] can have a transient protective effect for the sick child, his parents and his brothers and sisters if he does not does not last too long. Only, the different people concerned by this speaking space must understand the merits of each potential participant and agree to integrate it as a participant.

\section{Conflict of Interest}

None.

\section{Acknowledgements}

Morgan Hartman, Thanks for the proofreading this work.

\section{References}

[1] Jourdan C, Lachance J. Le dessin de famille: présentation, grille de cotation, éléments d'interprétation. Paris: EAPEditions et Applications Psychologiques; 2000.

[2] Libite R, Kelodjoue S, Dzossa AD, Fomo MA, Niekou R, Wounang R, et al. Enquête Démographique et de Santé et à Indicateurs Multiples. Yaoundé: Instiitut National de la Statistique; 2012.

[3] World Health Organization. Sickle cell anaemia. Agenda item 11.4. 59th World Health Assembly. 2006. Available on: http://www.who.int/gb/ebwha/pdf_files/WHA59-REC1/e/WH A59_2006_REC1.

[4] Gernet S, Mestre C, Runel-Belliard C. Du pays d'origine au pays «d'accueil»: perception de la maladie chez 26 familles drépanocytaires suivies au CHU de Bordeaux. J Pédiatrie Puériculture. 2012; 25 (6): 309-15. Available on: http://www.em-consulte.com/en/article/771297.

[5] Njifon Nsangou H, Falck J, Scelles R. Culture familiale de la drépanocytose et image du corps chez les enfants atteints. Ann Méd-Psychol Rev Psychiatr. 2019; Avalable on: http://www.sciencedirect.com/science/article/pii/S0003448719 302999.

[6] Organisation Mondiale de la Santé. Drépanocytose: une stratégie pour la Région africaine de l'OMS : rapport du Directeur régional. OMS. Bureau régional de l'Afrique; 2011. Available on: http://www.who.int/iris/handle/10665/1727. 
[7] Weatherall DJ, Clegg JB. Inherited haemoglobin disorders: an increasing global health problem. Bull World Health Organ. 2001; 79 (8): 704-12. Available on: http://www.scielosp.org/scielo.php?script=sci_abstract\&pid=S 0042-96862001000800005\&lng=en\&nrm=iso\&tlng=en.

[8] Pradère J, Drain É, Taïeb O, Dutray B, Abbal T, Champion M, et al. Le travail de guérison d'une maladie chronique de l'enfant : enjeux, processus et vulnérabilités. Psychiatr Enfant. 2008; 51 (1): 73-124. Available on: http://www.cairn.info/revue-la-psychiatrie-de-1-enfant-2008-1p-73.htm.

[9] d'Autume C, Cavadini R, Giannica D, Drain É, Giraud F, Moro $\mathrm{MR}$, et al. «Le sang de mon frère». Expérience de la greffe intrafamiliale à travers dessins et discours d'enfants drépanocytaires, «My brother's blood». The experience of an intrafamilial transplant through drawings and the words of drepanocytic children. Psychiatr Enfant. 2015; 57 (2): 355-408. Available

on: http://www.cairn.info/revue-la-psychiatrie-de-1-enfant-2014-2p-355.htm.

[10] Josset-Raffet E, Yi MK, Benkerrou M. La trajectoire corporelle et psychique de la douleur chez l'enfant atteint de drépanocytose. Neuropsychiatr Enfance Adolesc. 2016; 64 (2): 131-8 Available on: http://www.sciencedirect.com/science/article/pii/S0222961716 000040 .

[11] Mbassa Menick D, Ngoh F. Maltraitance psychologique d'enfants drépanocytaires au Cameroun : description et analyse de cas. Med Trop. 2001; (61): 163-168.

[12] Njifon Nsangou H. Drépanocytose et fratrie: une étude clinique exploratoire du vécu des frères et sœurs d'enfants atteints en contexte culturel camerounais. Université Paris Nanterre; 2019 Available on: http://www.theses.fr/s158870.

[13] Njifon Nsangou H, Scelles R. Sickle Cell Anemia, Representations and Care: Experience of a Brother of a Sick Child in Cameroon. Inherit Hemoglobin Disord. 2020; Available

on: https://www.intechopen.com/online-first/sickle-cell-anemia-re presentations-and-care-experience-of-a-brother-of-a-sick-child -in-cameroon.

[14] Keita T. Phénoménologie traditionnelle de l'enfance en Afrique. In: Itoua F, Tettekpoe DA, Traoré A, Keita T, M'Baye M, Essome Kotto, et al., éditeurs. Famille, enfant et développement en Afrique. Paris: Uneso; 1988. p. 99-139.

[15] Njifon Nsangou H, Scelles R. The Psychological Impact of Sickle Cell Disease on the Sick Child's Family. Acta Sci Paediatr. 2020; 3 (1): 01-9. Available on: https://actascientific.com/ASPE/ASPE-02-0209.php.

[16] Njifon Nsangou H, Scelles R. Drépanocytose et fratrie: regard croisé du vécu d'une sœur et d'un frère d'un enfant malade. J Pédiatrie Puériculture. 2019; 32 (2): 75-84. Available on: http://www.sciencedirect.com/science/article/pii/S0987798319 300295 .

[17] Tsala Tsala J-P. Familles africaines en thérapie : Clinique de la famille camerounaise. Paris: Editions L'Harmattan; 2009.

[18] Bonnet D. Rupture d'alliance contre rupture de filiation : le cas de la drépanocytose. In: Dozon J-P, Fassin D, éditeurs. Critique de la santé publique: une approche anthropologique. Paris: Balland; 2001.p. 257-80.
[19] Souley A. «Emassi»: Discours autour de la drépanocytose en milieu Haoussa au Niger. In: Lainé A, Bonnet D, Keclard L, Romana M, éditeurs. La Drépanocytose: Regards croisés sur une maladie orpheline. Paris: Karthala; 2004. p. 141-69.

[20] Scelles R. Dire ou ne pas dire en famille: processus de subjectivation du handicap au sein de la fratrie. Rev Fr Psychanal. 2008; (2): 485.

[21] Korff-Sausse S. Ce que parler veut dire... ou ne pas dire. Contraste. 2019; 49 (1): 39-58. Available on: https://www.cairn.info/revue-contraste-2019-1-page-39.htm.

[22] Scelles R. Liens fraternels et handicap: de l'enfance à l'âge adulte, souffrances et ressources. Toulouse: Érès; 2010.

[23] Kaës R. Les alliances inconscientes. Paris: Dunod; 2009.

[24] Scelles R. Formaliser le savoir sur le handicap et parler de leurs émotions: une question cruciale pour les frères et sœurs. Neuropsychiatr Enfance Adolesc. 2003; 51 (7): 391-8. Available on: http://www.sciencedirect.com/science/article/pii/S0222961703 001077 .

[25] Drain E, Pradère J, Taieb O, Dutray B, Champion M, Bonnet D, et al. Processus de guérison d'une maladie chronique: la drépanocytose traitée par allogreffe de cellules souches hématopoḯtiques: principaux résultats chez les adolescents. Journées Nationales de la SFPEADA.Société Française de Psychiatrie de l'Enfant et de l'Adolescent et Disciplines Associées, Neuropsychiatr Enfance Adolesc. 2008; 56 (4-5): 305-10. Available on: http://www.documentation.ird.fr/hor/fdi:010047377.

[26] Adegoke SA, Kuteyi EA. Psychosocial burden of sickle cell disease on the family, Nigeria : original research. Afr J Prim Health Care Fam Med. 2012; 4 (1): 1-6. Available on: https://journals.co.za/content/phcfm/4/1/EJC133881.

[27] Assimadi JK, Gbadoé AD, Nyadanu M. L'impact familial de la drépanocytose au Togo. Arch Pédiatrie. 2000; 7 (6): 615-20.

[28] Luboya E, Tshilonda J-CB, Ekila MB, Aloni MN. Répercussions psychosociales de la drépanocytose sur les parents d'enfants vivant à Kinshasa, République Démocratique du Congo: une étude qualitative. Pan Afr Med J. 2014; 19. Available http://www.ncbi.nlm.nih.gov/pmc/articles/PMC4282867/.

[29] Gesteira ECR, Bousso RS, Misko MD, Ichikawa CR de F, Oliveira PP de. Families of children with sickle cell disease: an integrative review. Online Braz J Nurs. 2016; 15 (2): 276-90. Available on: http://www.objnursing.uff.br/index.php/nursing/article/view/5 289.

[30] Anate K. L'imaginaire de la communication à travers le concept de parole en Afrique et en Occident. Commun Organ. 2002; (22): 12-21. Available on: http://journals.openedition.org/communicationorganisation/2773.

[31] Mappa S. Pouvoirs traditionnels et pouvoir d'Etat en Afrique: l'illusion universaliste. Paris: Karthala Editions; 1998. 210 p.

[32] Ortigue MC, Ortigue E. Oedipe africain. Plon; 1973.

[33] Tsala Tsala J-P. Test du dessin de famille et familles africaines. Le cas du Cameroun. Problèmes et méthodologie de la recherche. Ann Fac Arts Lett Sci Hum. 1990; 6 (1 et 2): 201-216. 
[34] Dufour P, Parron A, Salord T. De la pitié à la reconnaissance : identification, distanciation et invisibilisation dans le travail de care et dans les politiques du handicap. Cah Philos. 2014; (136) 44-57. Available on: https://www.cairn.info/resume.php?ID_ARTICLE=CAPH_13 6_0044.

[35] Scelles R. Penser l'atteinte du corps dans le lien à l'autre. Enfances Psy. 2002; 20 (4): 32-41. Available on: http://www.cairn.info/revue-enfances-et-psy-2002-4-p-32.htm.

[36] Korff Sausse S. Le miroir brisé: l'enfant handicapé, sa famille et le psychanalyste. Paris: Calmann-Lévy; 1996. 201 p. (Le passé recomposé).

[37] Tsala Tsala J-P. Secret de famille et clinique de la famille africaine. Divan Fam. 2010; (19): 31-46. Available on: http://www.cairn.info/revue-le-divan-familial-2007-2-p-31.ht $\mathrm{m}$.

[38] Ciccone A. Transmission psychique et fantasme de transmission. La parentalité à l'épreuve. Cah Psychol Clin. 2014; 43 (2): 59-79. Available on: https://www.cairn.info/revue-cahiers-de-psychologie-clinique2014-2-page-59.htm.
[39] Scelles R. La fratrie comme ressource. Cah Crit Thérapie Fam Prat Réseaux. 2004; 32 (1): 105-23. Available on: https://www.cairn.info/revue-cahiers-critiques-de-therapie-fa miliale-2004-1-page-105.htm.

[40] Bruggeman D. Conditions d'enquête et démarches méthodologiques de recherches «à domicile». Le chercheur sur le terrain des familles, Conditions for inquiry and methodological approach for research «at home». The researcher in family settings, Resumen. Sci Léducation - Pour LÈre Nouv. 2011; 44 (4): 51-73. Available on: https://www.cairn.info/revue-les-sciences-de-1-education-pour -1-ere-nouvelle-2011-4-page-51.htm.

[41] Rey J-F. Double bind et discours politique. Mots Lang Polit. 1995; 43 (1): 113-7. Available on: https://www.persee.fr/doc/mots_0243-6450_1995_num_43_1 1980.

[42] Tettamanti M, Chantraine F, Schmitt P, Curtis L. Collaborer avec les familles des jeunes adultes avec troubles psychiques débutants: vers un dialogue réflexif ? Illustration de cas. Ann Méd-Psychol Rev Psychiatr. 2019; 177 (8): 733-9. Available on:

http://www.sciencedirect.com/science/article/pii/S0003448719 300721. 